\title{
Intravitreal Pharmacotherapy in the Treatment of Retinitis Pigmentosa-related Cystoid Macular Oedema
}

\author{
Oya Donmez and Ali Osman Saatci ${ }^{2}$
}

1. TC Hitit University, Corum State Hospital, Corum, Turkey; 2. Dokuz Eylul University, Izmir, Turkey

$\mathrm{P}$ eripheral visual field constriction and night blindness are the main features of retinitis pigmentosa (RP). However, central vision is often impaired dramatically even in the early stages of the disease when macular complications such as cystoid macular oedema (CME) occur. The pathogenesis of RP-related CME is still not well explained. Therefore, several treatment alternatives such as topical, oral and systemic pharmacotherapy; laser photocoagulation and even vitreoretinal surgery are employed by the clinicians. In this review, we summarise the clinical data on intravitreal pharmacotherapeutic agents and focus mainly on the steroids and anti-vascular endothelial growth factor agents.

\section{Keywords}

Aflibercept, intravitreal injection, macula, macular oedema, Ozurdex ${ }^{\circledR}$, ranibizumab, retinitis pigmentosa, steroid, vascular endothelial growth factor

Disclosure: Oya Donmez and Ali Osman Saatci have nothing to disclose in relation to this article. No funding was received for the publication of this article. This study involves a review of the literature and did not involve any studies with human or animal subjects performed by any of the authors

Authorship: All named authors meet the International Committee of Medical Journal Editors (ICMJE) criteria for authorship for this manuscript, take responsibility for the integrity of the work as a whole and have given final approval for the version to be published.

open Access: This article is published under the Creative Commons Attribution Noncommercial License which permits any non-commercial use, distribution, adaptation, and reproduction provided the original author(s) and source are given appropriate credit.

Received: 9 March 2017

Accepted: 20 April 2017

Citation: European Ophthalmic Review, 2017;11(1):55-8

Corresponding Author: Ali Osman Saatci, Mustafa Kemal Sahil Bulvari, No: 73, A Blok D:9, 35320 Narlidere/ Izmir, Turkey. E: osman.saatci@yahoo.com
Retinitis pigmentosa (RP) is an inherited retinal dystrophy characterised with the progressive loss of photoreceptors. ${ }^{12}$ Night blindness together with the peripheral visual field loss is the most prominent clinical feature. ${ }^{1,2}$ Central vision is relatively spared up to the later stages of the disease process. ${ }^{3}$ However, when macular complications such as macular oedema arise, central vision is often dramatically impaired even in the early stages of the disease. The prevalence of cystoid macular oedema (CME) is reported to be $10-20 \%$ in the eyes of patients with RP.4,5

The pathogenesis of RP-related CME is still unclear. Blood-retinal barrier (BRB) impairment, retinal pigment epithelium (RPE) pump disturbance, inflammation, autoimmunity and vitreoretinal interface changes may be among the potential causes of CME. ${ }^{6-19}$

Fishman et al. ${ }^{6}$ examined 15 RP patients with vitreous fluorophotometry. All patients showed abnormally high concentrations of fluorescein within the vitreous which was a sign of BRB abnormality. Larsen et al.? demonstrated that BRB leakage was markedly increased in six RP patients with the help of ocular spectrofluorophotometry. Vinores et al. ${ }^{9}$ investigated the immunohistochemical staining for albumin on paraffin sections of 22 normal and 29 RP eyes. Electron microscopic immunocytochemical staining for albumin was performed on additional six normal and nine RP-affected eyes. Two-thirds of the eyes with RP demonstrated extravascular albumin in the inner portion of the posterior retina. This was evident even in the absence of CME but eyes with CME showed extensive BRB failure. Küchle et al..$^{10}$ analysed the BRB in patients with RP with a laser cell photometer in 56 eyes of 29 patients and found that aqueous flare values were higher in patients with RP than in controls; moreover, patients with RP-related CME had even higher values with a mean of 14.66 photon counts per millisecond compared with 9.65 for patients with RP but having no CME. RPE seems to lose polarised apical distribution in association with macular oedema and RP and cannot effectively pump out ions and fluid from the outer retina. ${ }^{11}$

Autoimmune processes and/or inflammation can be deemed as the hallmark of RP-related CME. Spalton et al. ${ }^{12}$ examined 25 patients with RP and all patients had an excessive number of vitreous cells; six even had exudates in the pre-equatorial fundus indistinguishable from pars planitis. They suggested that this might be a general response noticed in many types of tapetoretinal degeneration in reaction to actually degenerating photoreceptors or RPE. Furthermore, Heckenlively et al. ${ }^{13}$ looked for the presence of antiretinal antibodies in a group of 30 consecutive patients with CME and RP, 30 consecutive patients with RP but without CME and 50 normal subjects. Twenty-seven (90\%) of the patients with RP and CME had antiretinal protein antibody activity compared with three of 50 normal subjects (6\%) and only four of 30 patients (13\%) with RP but without coexistent CME.

Yoshida et al. ${ }^{14}$ studied the nature of inflammatory reaction in eyes of patients with RP. In 190 of 509 eyes (37.3\%) with RP, '1+' (5-9 cells per field) or more cells were observed in the 
Table 1: Intravitreal steroid administration in retinitis pigmentosa-related cystoid macular oedema

\begin{tabular}{|c|c|c|c|c|c|c|c|}
\hline Authors (year) & Study design & $\begin{array}{l}\text { No. of } \\
\text { eyes/cases }\end{array}$ & Agent & $\begin{array}{l}\text { Mean follow-up } \\
\text { period (months) }\end{array}$ & Outcome & $\begin{array}{l}\text { Reinjection } \\
\text { (eyes) }\end{array}$ & Conclusion \\
\hline $\begin{array}{l}\text { Saraiva et al. }{ }^{31} \\
\text { (2003) }\end{array}$ & Case report & $2 / 1$ & 4 mg IVTA & 8 & $\begin{array}{l}\text { Improvement in BCVA (1 of } 2 \\
\text { eyes), improvement in CMT } \\
\text { (all eyes) }\end{array}$ & None & Useful in some selected cases \\
\hline $\begin{array}{l}\text { Ozdemir et al. }{ }^{32} \\
(2005)\end{array}$ & Case series & $5 / 5$ & 4 mg IVTA & 6.8 & $\begin{array}{l}\text { Improvement in BCVA ( } 2 \text { of } 5 \\
\text { eyes), improvement in CMT } \\
\text { (all eyes) }\end{array}$ & 3 & $\begin{array}{l}\text { Despite good anatomic results, } \\
\text { no BCVA improvement in some } \\
\text { cases }\end{array}$ \\
\hline $\begin{array}{l}\text { Wang et al. }{ }^{33} \\
\text { (2006) }\end{array}$ & Case series & $4 / 2$ & 4 mg IVTA & 1 & $\begin{array}{l}\text { Improvement in BCVA and CMT } \\
\text { (all eyes) }\end{array}$ & NR & A promising treatment option \\
\hline $\begin{array}{l}\text { Scorolli et al. }{ }^{34} \\
(2007)\end{array}$ & $\begin{array}{l}\text { Prospective } \\
\text { nonrandomised } \\
\text { comparative } \\
\text { trial }\end{array}$ & $20 / 20$ & 4 mg IVTA & 12 & $\begin{array}{l}\text { No significant changes in BCVA, } \\
\text { but significant improvement in } \\
\text { CMT }\end{array}$ & None & $\begin{array}{l}\text { Useful in selected cases but its } \\
\text { efficacy seems limited }\end{array}$ \\
\hline $\begin{array}{l}\text { Saatci et al. }{ }^{36} \\
\text { (2013) }\end{array}$ & Case report & $2 / 1$ & $\begin{array}{l}0.7 \mathrm{mg} \text { DEX } \\
\text { implant }\end{array}$ & 7 & $\begin{array}{l}\text { Improvement in BCVA and CMT } \\
\text { (all eyes) }\end{array}$ & None & $\begin{array}{l}\text { A therapeutic option especially } \\
\text { in cases unresponsive to other } \\
\text { treatments }\end{array}$ \\
\hline $\begin{array}{l}\text { Alhassan et al. }{ }^{37} \\
\text { (2013) }\end{array}$ & Case report & $1 / 1$ & $\begin{array}{l}0.7 \mathrm{mg} \text { DEX } \\
\text { implant }\end{array}$ & 1 & Improvement in BCVA and CMT & NR & $\begin{array}{l}\text { Even provide anatomical and } \\
\text { functional improvements in the } \\
\text { fellow eye }\end{array}$ \\
\hline $\begin{array}{l}\text { Ahn et al. }{ }^{38} \\
(2014)\end{array}$ & Case report & $2 / 1$ & $\begin{array}{l}0.7 \mathrm{mg} \text { DEX } \\
\text { implant }\end{array}$ & 12 & $\begin{array}{l}\text { Improvement in BCVA and CMT } \\
\text { (all eyes) }\end{array}$ & 2 & Useful with limited efficacy \\
\hline $\begin{array}{l}\text { Ornek et al. }{ }^{39} \\
(2016)\end{array}$ & Case report & $2 / 1$ & $\begin{array}{l}0.7 \mathrm{mg} \text { DEX } \\
\text { implant }\end{array}$ & 6 & $\begin{array}{l}\text { Improvement in BCVA and CMT } \\
\text { (all eyes) }\end{array}$ & NR & $\begin{array}{l}\text { Rapid response in resistant } \mathrm{CME} \\
\text { cases }\end{array}$ \\
\hline $\begin{array}{l}\text { Mansour et al. }{ }^{30} \\
(2017)\end{array}$ & $\begin{array}{l}\text { Retrospective } \\
\text { case series }\end{array}$ & $45 / 34$ & $\begin{array}{l}0.7 \mathrm{mg} \text { DEX } \\
\text { implant }\end{array}$ & 15.5 & $\begin{array}{l}\text { At month } 3 \text {, visual acuity } \\
\text { improved to } 20 / 47 \text { from the } \\
\text { baseline of } 20 / 81\end{array}$ & 14 & $\begin{array}{l}\text { BCVA improved in half of } \\
\text { patients at the fourth month but } \\
\text { cataracts ensued with multiple } \\
\text { injections }\end{array}$ \\
\hline
\end{tabular}

BCVA = best corrected visual acuity; CME = cystoid macular oedema; $C M T=$ central macular thickness; $D E X=$ dexamethasone; IVTA = intravitreal triamcinolone; NR = not reported.

Figure 1: A 55-year-old woman with retinitis pigmentosa-related bilateral cystoid macular oedema

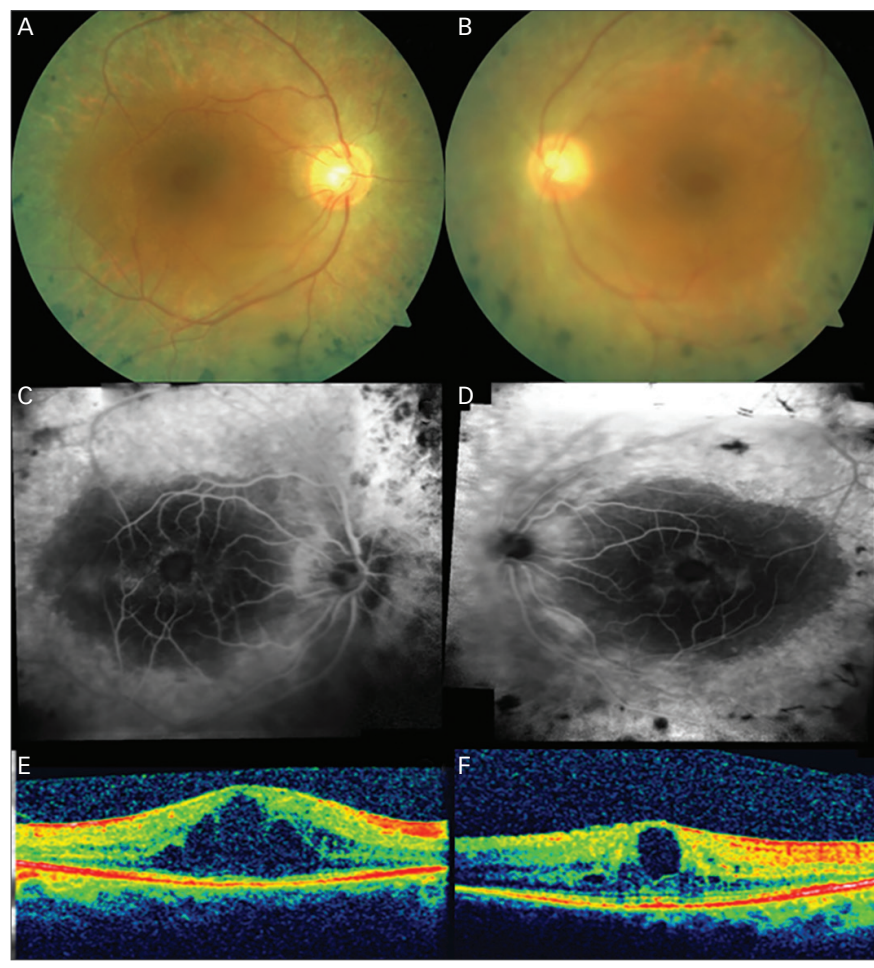

Colour fundus pictures (A, B); composite fluorescein angiographic pictures (C, D); optic coherence tomographic pictures of both eyes at presentation $(E, F)$. anterior vitreous cavity. A strong inflammatory reaction with ' $2+$ ' cells (10-30 cells per field) was associated with younger age. The levels of various proinflammatory cytokines and chemokines including monocyte chemotactic protein-1 were increased both in the aqueous humour and vitreous fluid of RP patients compared with the levels in control patients. ${ }^{14}$

Vitreoretinal abnormalities can be a factor in the development of CME in RP patients. ${ }^{15-17}$ Kim et al. ${ }^{16}$ detected CME in 46 of 220 eyes with RP with the spectral domain optic coherence tomography (SD-OCT). Vitreomacular interface abnormalities including epiretinal membrane development and vitreomacular traction were evident in over $40 \%$ of patients and the presence of vitreoretinal abnormalities was significantly higher in eyes with CME than in eyes without CME (64.1\% versus $36.8 \%)$. Spontaneous release of vitreoretinal traction may alleviate the RP-related CME as soon as the spontaneous resolution of traction occurs. ${ }^{17}$ It is also speculated that vitreoretinal abnormalities may induce a mechanical damage to the Muller cells that are an essential element for visual transduction and retinal homeostasis as Muller cells play an important role in the fluid dynamics. 18,19

\section{Treatment}

Various treatment alternatives including topical (nonsteroidal antiinflammatory agents, carbonic anhydrase inhibitors), oral agents (carbonic anhydrase inhibitors, steroids), grid laser photocoagulation and vitreoretinal surgery were utilised in the treatment of RP-related CME. ${ }^{11,20-25}$ In this review we focus on the intravitreal pharmacotherapy. 
Table 2: Intravitreal anti-vascular endothelial growth factor administration in retinitis pigmentosa-related cystoid macular oedema

\begin{tabular}{|c|c|c|c|c|c|c|c|}
\hline $\begin{array}{l}\text { Authors } \\
\text { (year) }\end{array}$ & Study design & $\begin{array}{l}\text { No of eyes/ } \\
\text { cases }\end{array}$ & Agent & $\begin{array}{l}\text { Mean follow-up } \\
\text { period (months) }\end{array}$ & Outcome & $\begin{array}{l}\text { Reinjection } \\
\text { (eyes) }\end{array}$ & Conclusion \\
\hline $\begin{array}{l}\text { Melo } \\
\text { et al. }{ }^{44}(2007)\end{array}$ & Case report & $2 / 2$ & 1.25 mg bevacizumab & 4 & $\begin{array}{l}\text { No improvement in BCVA } \\
\text { and } \mathrm{CMT}\end{array}$ & NR & Ineffective \\
\hline $\begin{array}{l}\text { Yuzbasioglu } \\
\text { et al. }{ }^{45} \text { (2009) }\end{array}$ & Prospective study & $13 / 7$ & $1.25 \mathrm{mg}$ bevacizumab & 10.2 & $\begin{array}{l}\text { Improvement in BCVA } \\
\text { and } \mathrm{CMT}\end{array}$ & 7 & Effective \\
\hline $\begin{array}{l}\text { Querques } \\
\text { et al. }{ }^{46}(2009)\end{array}$ & Case report & $1 / 1$ & $\begin{array}{l}0.3 \mathrm{mg} \text { pegaptanib } \\
\text { sodium }\end{array}$ & 4 & $\begin{array}{l}\text { Improvement in BCVA and } \\
\text { none in CMT }\end{array}$ & NR & $\begin{array}{l}\text { May be beneficial } \\
\text { in combination with } \\
\text { acetazolamide }\end{array}$ \\
\hline $\begin{array}{l}\text { Artunay } \\
\text { et al. }{ }^{47} \text { (2009) }\end{array}$ & $\begin{array}{l}\text { Prospective } \\
\text { controlled } \\
\text { interventional study }\end{array}$ & $15 / 15$ & $0.5 \mathrm{mg}$ ranibizumab & 6 & $\begin{array}{l}\text { No significant changes in } \\
\text { BCVA, significant change } \\
\text { in CMT }\end{array}$ & NR & $\begin{array}{l}\text { A promising new therapeutic } \\
\text { approach }\end{array}$ \\
\hline $\begin{array}{l}\text { Shah } \\
\text { et al. }{ }^{48}(2009)\end{array}$ & Case report & $1 / 1$ & $0.5 \mathrm{mg}$ ranibizumab & 6 & $\begin{array}{l}\text { No improvement in BCVA, } \\
\text { improvement of CMT }\end{array}$ & 1 & Effective \\
\hline $\begin{array}{l}\text { Moustafa } \\
\text { et al. }{ }^{49}(2015)\end{array}$ & Case report & $1 / 1$ & 0.5 mg aflibercept & 6 & $\begin{array}{l}\text { Improvement in BCVA and } \\
\mathrm{CMT} \text {, no change in mfERG }\end{array}$ & None & Effective \\
\hline $\begin{array}{l}\text { Strong } \\
\text { et al. } .^{43}(2016)\end{array}$ & Case report & $1 / 1$ & $2 \mathrm{mg}$ aflibercept & 19 & $\begin{array}{l}\text { Improvement in BCVA } \\
\text { and } \mathrm{CMT}\end{array}$ & 1 & $\begin{array}{l}\text { Aflibercept may be more } \\
\text { effective than other anti- } \\
\text { VEGFs }\end{array}$ \\
\hline
\end{tabular}

BCVA = best corrected visual acuity; $C M T=$ central macular thickness; $m f E R G=$ multifocal electroretinogram; NR = not reported; VEGF = vascular endothelial growth factor.

\section{Intravitreal steroids}

Steroids exert their effect via several mechanisms such as reduction in synthesis and release of proinflammatory cytokines, suppression of the production and migration of inflammatory cells, and suppression of the autoimmune process and restoration of the integrity of BRB..$^{26-30}$ The previous reports on intravitreal steroid administration in eyes with RP-related $\mathrm{CME}^{30-39}$ are summarised in Table 1. The treatment effect of dexamethasone implant can be seen in a case with bilateral RP-related CME (Figures 1 and 2).

The most important drawbacks in the use of intravitreal steroids in RP-related CME are temporary drug effect and risk of ocular hypertension and cataract formation especially with consecutive injections. ${ }^{30}$

\section{Intravitreal anti-vascular endothelial growth factor agents}

Intravitreal anti-vascular endothelial growth factor (VEGF) administration is shown to be very effective in VEGF-driven disease processes by reversing mainly the VEGF-driven BRB disruption. .04,41 $^{402}$

Salom et al. ${ }^{42}$ quantified the VEGF-A levels in aqueous humour of 16 eyes of 16 patients with RP. They found that aqueous VEGF-A levels were markedly lower in eyes with RP than in control patients. Strong et al. ${ }^{43}$ hypothesised that a localised VEGF production under pathologic conditions, for example by Muller cells, may contribute to CME formation in RP patients and this fact may also be the reason for the rarity of peripheral neovascularisation in eyes with RP. The previous reports on intravitreal anti-VEGF agent administered in eyes with RP-related $\mathrm{CME}^{43-49}$ are summarised in Table 2.

\section{Intravitreal autologous bone marrow-derived heamatopoietic stem cell transplantation}

Siqueira et al.50 published a case with RP-related CME who received treatment with an intravitreal injection of autologous bone marrowderived heamatopoietic stem cell (auto-BMHSCT) and showed complete
Figure 2: Fifteen months following the three-dexamethasone implant administration

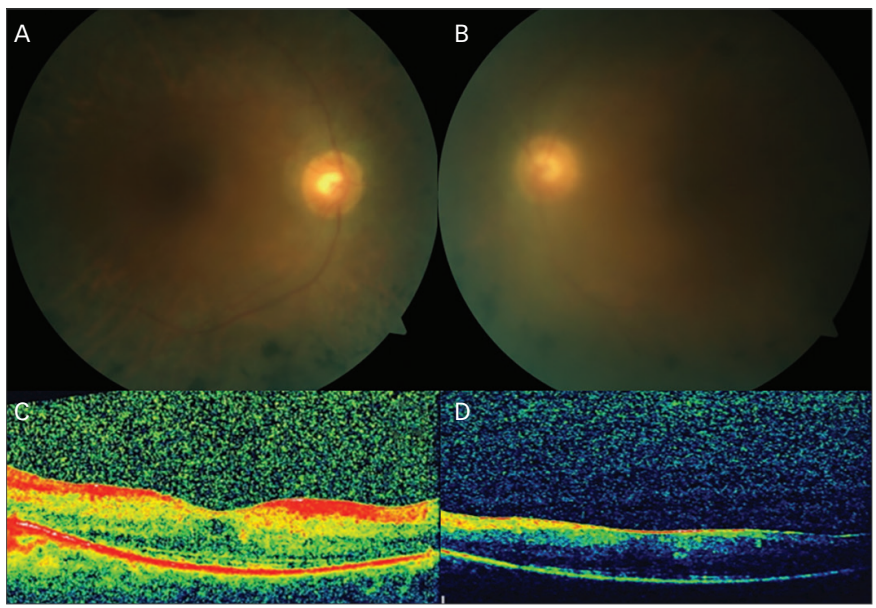

Colour pictures ( $A, B$; please note that growing cataract is blurring the fundus appearance); optical coherence tomographic pictures of both eyes $(C, D)$.

resolution of CME 7 days after the injection. This effect lasted for a month. Visual acuity was improved to 20/50 from 20/32. Macular sensitivity measured by the microperimetry was also improved. Authors speculated that auto-BMHSCT might restore the BRB via its paracrine effects and thereby provided the resolution of the oedema.

\section{Comments}

There is yet no proven treatment for RP-related CME and no randomised controlled studies with a sufficient number of patients have been performed. Intravitreal steroids and anti-VEGF agents are reported to have some effect on RP-related CME but the durability of treatment effect and the selection of agent (anti-VEGF or steroids) are highly controversial. Thereby, we intend to review the current status of the intravitreal pharmacotherapy in the treatment of RP-related CME and share some of the latest data with the ophthalmic community. $]$ 
1. Hamel C, Retinitis pigmentosa, Orphanet J Rare Dis, 2006;1:40. Marmor MF, Aguirre G, Arden G, Retinitis pigmentosa. A symposium on terminology and methods of examination, ophthalmology, 1983;90:126-31

3. Ikeda Y, Hisatomi T, Yoshida N, et al., The clinical efficacy of a topical dorzolamide in the management of cystoid macular edema in patients with retinitis pigmentosa, Graefes Arch Clin Exp Ophthalmol, 2012;250:809-14.

4. Fishman GA, Maggiano JM, Fishman M, Foveal lesions seen in retinitis pigmentosa, Arch Ophthalmol, 1977;95:1993-6.

5. Fenkenhour $\mathrm{CL}$, Choromokos E, Weinstein J, et al., Cystoid macular oedema in retinitis pigmentosa, Trans Am Acad Ophthalmol Otolaryngol, 1977;83:515-21.

6. Fishman GA, Cunha-Vaz J, Salzano T, Vitreous fluorophotometry in patients with retinitis pigmentosa, Arch Ophthalmol, 1981;:99:1202-7.

7. Larsen M, Engler CB, Haim M, et al., Blood-retina barrier permeability is independent of trace substance lipid solubility in retinitis pigmentosa and in the healthy eye, Int Ophthalmol, 1998:21:229-34

8. Mallick KS, Zeimer RC, Fishman GA, et al., Transport of fluorescein in the ocular posterior segment in retinitis pigmentosa, Arch Ophthalmol, 1984;102:691-6.

9. Vinores SA, Küchle M, Derevjanik NL, et al., Blood-retinal barrier breakdown in retinitis pigmentosa: light and electron microscopic immunolocalization, Histol Histopathol, 1995;10:913-23.

10. Küchle M, Nguyen NX, Schalnus R, et al., Quantification of disorders of the blood-aqueous humor barrier in retinitis pigmentosa - initia results, Klin Monbl Augenheilkd, 1994;204:211-6.

11. Cox SN, Hay E, Bird AC, Treatment of chronic macular edem with acetazolamide, Arch Ophthalmol, 1988:106:1190-5.

12. Spalton DJ, Bird AC, Cleary PE, Retinitis pigmentosa and retinal oedema, Br J Ophthalmol, 1978;62:174-82.

13. Heckenlively JR, Jordan BR, Aptsiauri $N$, Association of antiretinal antibodies and cystoid macular edema in patients with retinitis pigmentosa, Am J Ophthalmol 1999;127:565-73.

14. Yoshida N, Ikeda Y, Notomi S, et al., Clinical evidence of sustained chronic inflammatory reaction in retinitis pigmentosa, Ophthalmology, 2013;120:100-5.

15. Triolo G, Pierro L, Parodi MB, et al., Spectral domain optica coherence tomography findings in patients with retinitis pigmentosa, Ophthalmic Res, 2013;50:160-4.

16. Kim YJ, Joe SG, Lee DH, et al., Correlations between spectral-domain OCT measurements and visual acuity in cystoid macular edema associated with retinitis pigmentosa, Invest Ophthalmol Vis Sci, 2013:54:1303-9.

17. Takezawa M, Tetsuka S, Kakehashi A, Tangential vitreous traction: a possible mechanism of development of cystoid traction: a possible mechanism of development of cystoid 2011:5:245-8.

18. Garcia-Arumi J, Martinez V, Sararols $L$, et al., Vitreoretinal surgery for cystoid macular edema associated with retinitis pigmentosa, Ophthalmology, 2003;110:1164-9.
19. Schepens CL, Avila MP, Jalkh AE, et al., Role of the vitreous in cystoid macular edema, Surv Ophthalmol, 1984:28:499-504.

20. Grover S, Apuskin MA, Fishman GA, Topical dorzolamide for the treatment of cystoid macular edema in patients with retinitis pigmentosa, Am I Ophthalmol, 2006:141:850-8.

21. Fishman GA, Gilberd LD, Fiscella RG, et al., Acetazolamide for treatment of chronic macular edema in retinitis pigmentosa Arch Ophthalmol, 1989; 107:1445-52.

22. Wolfensberger $\mathrm{TJ}$, The role of carbonic anhydrase inhibitor in the management of macular edema, Doc Ophthalmol, 1999;97:387-97.

23. Newsome DA, Blackharski PA, Grid photocoagulation for macular edema in patients with retinitis pigmentosa, Am J Ophthalmol, 1987;103:161-6.

24. Giusti C, Forte R, Vingolo EM, Deflazacort treatment of cystoid macular edema in patients affected by retinitis pigmentosa: a pilot study, Eur Rev Med Pharmacol Sci, 2002;6:1-8.

25. Gelman SK, Gorin MB, Significant macular edema in a patient with cone dystrophy and improvement with acetazolamide treatment, Retin Cases Brief Rep, 2014:8:300-5.

26. Jonas JB, Hayler JK, Söfker A, et al., Intravitreal injection of crystalline cortisone as adjunctive treatment of proliferativ diabetic retinopathy, Am J Ophthalmol, 2001;131:468-71.

27. Moshfeghi DM, Kaiser PK, Scott IU, et al., Acute endophthalmitis following intravitreal triamcinolone acetonide injection, Am J Ophthalmol, 2003;136:791-6.

28. Roth DB, Chieh J, Spirn MJ, et al., Noninfectious endophthalmitis associated with intravitreal triamcinolone injection, Arch Ophthalmol, 2003;121:1279-82.

29. Penfold PL, Wen L, Madigan MC, et al., Triamcinolone acetonide modulates permeability and intercellular adhesion molecule-1 (ICAM-1) expression of the ECV304 cell line: implications for macular degeneration, Clin Exp Immunol, 2000;121:458-65.

30. Mansour AM, Sheheitli $H$, Kucukerdonmez $C$, et al. Intravitreal dexamethasone implant in retinitis pigmentosa-related cystoid macular edema, Retina 2017 doi: 10.1097/LE .0000000000001542. [Epub ahead of print]

31. Saraiva VS, Sallum JM, Farah ME, Treatment of cystoid macular edema related to retinitis pigmentosa with intravitreal triamcinolone acetonide, Ophthalmic Surg Lasers Imaging, 2003;34:398-400.

32. Ozdemir H, Karacorlu M, Karacorlu S, Intravitreal triamcinolone acetonide for treatment of cystoid macular oedema in patients with retinitis pigmentosa, Acta Ophthalmol Scand, 2005;83:248-51.

33. Wang $\mathrm{C}, \mathrm{Hu}$ J, Bernstein PS, et al., Intravitreal injection of triamcinolone acetonide for macular edema due to retinitis pigmentosa and other retinal diseases, Adv Exp Med Biol, 2006;572:309-14.

34. Scorolli L, Morara M, Meduri A, et al., Treatment of cystoid macular edema in retinitis pigmentosa with intravitreal triamcinolone, Arch Ophthalmol, 2007:125:759-64.

35. Srour M, Querques $\mathrm{G}$, Leveziel $\mathrm{N}$, et al., Intravitreal dexamethasone implant (Ozurdex) for macular edema secondary to retinitis pigmentosa, Graefes Arch Clin Exp ophthalmol, 2013;251:1501-6.
36. Saatci $A O$, Selver $O B$, Seymenoglu $G$, et al., Bilateral intravitrea dexamethasone implant for retinitis pigmentosa related macular edema, Case Rep Ophthalmol, 2013:4:53-8.

37. Alhassan M, Quintyn JC, Unilateral intravitreal dexamethason implant for bilateral retinitis pigmentosa related macular edema, Graefes Arch Clin Exp Ophthalmol, 2013;251:2827-8.

38. Ahn SJ, Kim KE, Woo SJ, et al., The effect of an intravitreal dexamethasone implant for cystoid macular edema in retinitis pigmentosa: a case report and literature review, Ophthalmic Surg Lasers Imaging Retina, 2014;45:160-4.

39. Örnek N, Örnek K, Erbahçeci IE, Intravitreal dexamethasone implant (Ozurdex) for refractory macular edema secondary to retinitis pigmentosa, Turk J Ophthalmol, 2016;46:179-81:

40. Deissler H, Deissler H, Lang S, et al., VEGF-induced effects on proliferation, migration and tight junctions are restored by ranibizumab (lucentis) in microvascular retinal endothelial cells, Br J Ophthalmol, 2008:92:839-43.

41. Nguyen QD, Tatlipinar S, Shah SM et al, vascular endothelial growth factor is a critical stimulus for diabetic macular edema, Am J Ophthalmol, 2006:142:961-9.

42. Salom D, Diaz-Llopis M, García-Delpech S, et al., Aqueous humor levels of vascular endothelial growth factor in retinitis pigmentosa, Invest Ophthalmol Vis Sci, 2008;49:3499-502.

43. Strong SA, Gurbaxani A, Michaelides M, Treatment of retinitis pigmentosa-associated cystoid macular oedema using intravitreal aflibercept (Eylea) despite minimal response to Ranibizumab (Lucentis): a case report, Case Rep Ophthalmol, 2016; 7:389-97.

44. Melo GB, Farah ME, Aggio FB, Intravitreal injection of bevacizumab for cystoid macular edema in retinitis pigmentosa Acta Ophthalmol Scand 2007:85:461-3.

45. Yuzbasioglu E, Artunay O Rasier R, et a Intravitreal bevacizumab (Avastin) injection in retinitis pigmentosa Curr Eye Res, 2009;34:231-7.

46. Querques G, Prascina F, laculli C, et al., Intravitreal pegaptanib sodium (Macugen) for refractory cystoid macular edema in pericentral retinitis pigmentosa, Int Ophthalmol, 2009;29:103-7.

47. Artunay O, Yuzbasioglu E, Rasier R, et al., Intravitreal ranibizumab in the treatment of cystoid macular edema associated with retinitis pigmentosa, J Ocul Pharmacol Ther , 2009;25:545-50.

48. Shah $\mathrm{CR}, \mathrm{Brent} \mathrm{MH}$, Treatment of retinitis pigmentosa-related cystoid macular edema with intravitreous ranibizumab, Retin Cases Brief Rep, 2010;4:291-3.

49. Moustafa GA, Moschos MM, Intravitreal aflibercept (Eylea) injection for cystoid macular edema secondary to retinitis pigmentosa - a first case report and short review of the pigmentosa - a first case report and short r.

50. Siqueira RC, Messias A, voltarelli JC, et al., Resolution of macular oedema associated with retinitis pigmentosa after intravitreal use of autologous BM-derived hematopoietic stem cell transplantation, Bone Marrow Transplant 2013;48:612-3. 